\title{
Estramustine-Induced Suicidal Erythrocyte Death
}

\author{
Rosi Bissinger ${ }^{\mathrm{a}}$ Paola Modicano ${ }^{\mathrm{a}, \mathrm{b}}$ Leonie Frauenfeld ${ }^{\mathrm{a}}$ Elisabeth Lang ${ }^{\mathrm{a}}$ \\ Janin Jacobi ${ }^{a}$ Caterina Faggio ${ }^{b}$ Florian Lang ${ }^{a}$ \\ ${ }^{a}$ Department of Physiology, University of Tuebingen, Tuebingen, Germany; ${ }^{b}$ Department of Biological \\ and Environmental Sciences, University of Messina, S.Agata-Messina, Italy
}

\section{Key Words}

Phosphatidylserine $\cdot$ Estramustine $\cdot$ Calcium $\cdot$ Cell volume $\bullet$ Eryptosis

\begin{abstract}
Background: The nitrogen mustard derivative of estradiol-17 $\beta$-phosphate estramustine is used for the treatment of prostate cancer. Estramustine may trigger suicidal death of cancer cells. Side effects of estramustine include anemia. At least in theory, estramustine could cause anemia by stimulation of eryptosis, the suicidal death of erythrocytes. Hallmarks of eryptosis include cell shrinkage, increased cytosolic $\mathrm{Ca}^{2+}$ activity $\left(\left[\mathrm{Ca}^{2+}\right]\right)$, ceramide formation and phosphatidylserine translocation to the outer leaflet of the cell membrane with phosphatidylserine exposure at the erythrocyte surface. Eryptosis is stimulated by increase of cytosolic $\mathrm{Ca}^{2+}$ activity $\left(\left[\mathrm{Ca}^{2+}\right]_{\mathrm{i}}\right)$. The present study explored whether estramustine triggers eryptosis. Methods: $\left[\mathrm{Ca}^{2+}\right]_{i}$ was estimated from Fluo3 fluorescence, cell volume from forward scatter, phosphatidylserine exposure from annexin $\mathrm{V}$ binding, and hemolysis from hemoglobin release. Results: A $24 \mathrm{~h}$ exposure to estramustine $(\leq 100 \mu \mathrm{M})$ significantly increased $\left[\mathrm{Ca}^{2+}\right]_{\mathrm{i}}$ increased annexin $\mathrm{V}$ binding and increased hemoglobin release. The effect of estramustine on annexin $\mathrm{V}$ binding was significantly blunted by removal of extracellular $\mathrm{Ca}^{2+}$. Conclusions: Estramustine stimulates both, eryptosis and hemolysis. The estramustine induced translocation of phosphatidylserine to the cell surface is at least partially due to increase of cytosolic $\mathrm{Ca}^{2+}$ activity.
\end{abstract}




\section{Introduction}

Estramustine, a nitrogen mustard derivative of estradiol-17 $\beta$-phosphate, is widely used alone or in combination with other anticancer drugs for the treatment of prostate cancer $[1,2]$. Estramustine is effective by suppressimg the dynamics of microtubules [1] thus interfering with mitosis [3]. Moreover, estramustine has been shown to trigger apoptosis [1, $4,5]$. Side effects of treatment with combinations containing estramustine include anemia [6-10], which is a risk factor of patient survival [11].

At least in theory, anemia following cytostatic treatment could involve suicidal erythrocyte death or eryptosis, which is characterized by erythrocyte shrinkage and breakdown of phosphatidylserine asymmetry of the erythrocyte cell membrane $[12,13]$. Eryptosis may be triggered by $\mathrm{Ca}^{2+}$ entry through $\mathrm{Ca}^{2+}$ permeable cation channels with subsequent increase of cytosolic $\mathrm{Ca}^{2+}$ activity $\left(\left[\mathrm{Ca}^{2+}\right]_{\mathrm{i}}\right)[14,15]$. The increase of $\left[\mathrm{Ca}^{2+}\right]_{\mathrm{i}}$ leads to activation of $\mathrm{Ca}^{2+}$ sensitive $\mathrm{K}^{+}$channels [16], $\mathrm{K}^{+}$exit, hyperpolarization, $\mathrm{Cl}^{-}$exit and thus cell shrinkage due to cellular loss of $\mathrm{KCl}$ with osmotically obliged water [17]. The increase of $\left[\mathrm{Ca}^{2+}\right]_{\mathrm{i}}$ further triggers translocation of phosphatidylserine to the outer leaflet of the erythrocyte cell membrane with exposure of phosphatidylserine at the erythrocyte surface [18]. $\mathrm{Ca}^{2+}$ sensitivity of eryptosis is increased by ceramide [19]. Eryptosis can further be stimulated by energy depletion [20] and caspase activation [21-25]. Regulation of eryptosis further involves AMP activated kinase AMPK [15], cGMP dependent protein kinase [26], Janus activated kinase JAK3 [27], casein kinase $1 \alpha[28,29]$, p38 kinase [30], PAK2 kinase [31] as well as sorafenib [32] and sunitinib [33] sensitive kinases.

Eryptosis may be stimulated by a wide variety of xenobiotics [33-64]. Moreover, excessive eryptosis contributes to the pathophysiology of several clinical disorders [12] including diabetes $[25,65,66]$, renal insufficiency [67], hemolytic uremic syndrome [68], sepsis [69], malaria [70-74], sickle cell disease [75], Wilson's disease [73], iron deficiency [76], malignancy [77], phosphate depletion [78], and metabolic syndrome [60].

The present study explored, whether estramustine triggers eryptosis, and if so, whether the effect involves alterations of erythrocyte $\left[\mathrm{Ca}^{2+}\right]_{\mathrm{i}^{*}}$

\section{Materials and Methods}

Erythrocytes, solutions and chemicals

Leukocyte depleted erythrocytes were kindly provided by the blood bank of the University of Tübingen. The study is approved by the ethics committee of the University of Tübingen (184/2003V). Erythrocytes were incubated in vitro at a hematocrit of $0.4 \%$ in Ringer solution containing (in $\mathrm{mM}$ ) $125 \mathrm{NaCl}, 5 \mathrm{KCl}, 1$ $\mathrm{MgSO}_{4}, 32 \mathrm{~N} 2$ hydroxyethylpiperazine $\mathrm{N} 2$ ethanesulfonic acid (HEPES), 5 glucose, $1 \mathrm{CaCl}_{2} ; \mathrm{pH} 7.4$ at $37^{\circ} \mathrm{C}$ for $48 \mathrm{~h}$. Where indicated, erythrocytes were exposed to estramustine (Sigma-Aldrich, Germany) at the indicated concentrations. Estramustine was dissolved in $\mathrm{H}_{2} \mathrm{O}$ and added at concentrations of up to $100 \mu \mathrm{M}$. The addition of estramustine increased osmolarity by $<0.05 \%$, an effect not leading to appreciable cell shrinkage and not sufficient to trigger eryptosis [79]. In $\mathrm{Ca}^{2+}$ free Ringer solution, $1 \mathrm{mM} \mathrm{CaCl}_{2}$ was substituted by $1 \mathrm{mM}$ glycol bis(2 aminoethylether) N,N,N',N' tetraacetic acid (EGTA).

\section{FACS analysis of annexin $V$ binding and forward scatter}

After incubation under the respective experimental condition, $50 \mu \mathrm{l}$ cell suspension was washed in Ringer solution containing $5 \mathrm{mM} \mathrm{CaCl}_{2}$ and then stained with Annexin V FITC (1:200 dilution; ImmunoTools, Friesoythe, Germany) in this solution at $37^{\circ} \mathrm{C}$ for 20 min under protection from light. In the following, the forward scatter (FSC) of the cells was determined, and annexin V fluorescence intensity was measured in FL 1 with an excitation wavelength of $488 \mathrm{~nm}$ and an emission wavelength of $530 \mathrm{~nm}$ on a FACS Calibur (BD, Heidelberg, Germany). 
Measurement of intracellular $\mathrm{Ca}^{2+}$

After incubation erythrocytes were washed in Ringer solution and then loaded with Fluo 3/AM (Biotium, Hayward, USA) in Ringer solution containing $5 \mathrm{mM} \mathrm{CaCl}_{2}$ and $2 \mu \mathrm{M}$ Fluo 3/AM. The cells were incubated at $37^{\circ} \mathrm{C}$ for $30 \mathrm{~min}$ and washed twice in Ringer solution containing $5 \mathrm{mM} \mathrm{CaCl}{ }_{2}$. The Fluo $3 / \mathrm{AM}$ loaded erythrocytes were resuspended in $200 \mu \mathrm{l}$ Ringer. Then, $\mathrm{Ca}^{2+}$ dependent fluorescence intensity was measured in fluorescence channel FL 1 in FACS analysis.

\section{Measurement of hemolysis}

For the determination of hemolysis the samples were centrifuged ( $3 \mathrm{~min}$ at $400 \mathrm{~g}$, room temperature) after incubation, and the supernatants were harvested. As a measure of hemolysis, the hemoglobin ( $\mathrm{Hb})$ concentration of the supernatant was determined photometrically at $405 \mathrm{~nm}$. The absorption of the supernatant of erythrocytes lysed in distilled water was defined as $100 \%$ hemolysis.

\section{Determination of ceramide formation}

For the determination of ceramide, a monoclonal antibody-based assay was used. To this end, cells were stained for 1 hour at $37^{\circ} \mathrm{C}$ with $1 \mu \mathrm{g} / \mathrm{ml}$ anti ceramide antibody (clone MID 15B4, Alexis, Grünberg, Germany) in PBS containing 0.1\% bovine serum albumin (BSA) at a dilution of 1:5. The samples were washed twice with PBS-BSA. Subsequently, the cells were stained for 30 minutes with polyclonal fluorescein isothiocyanate (FITC) conjugated goat anti-mouse IgG and IgM specific antibody (Pharmingen, Hamburg, Germany) diluted 1:50 in PBS-BSA. Unbound secondary antibody was removed by repeated washing with PBS-BSA. The samples were then analyzed by flow cytometric analysis with an excitation wavelength of 488 $\mathrm{nm}$ and an emission wavelength of $530 \mathrm{~nm}$. As control, secondary antibody alone was used.

\section{Statistics}

Data are expressed as arithmetic means \pm SEM. As indicated in the figure legends, statistical analysis was made using ANOVA with Tukey's test as post test and $t$ test as appropriate. $\mathrm{n}$ denotes the number of different erythrocyte specimens studied. Since different erythrocyte specimens used in distinct experiments are differently susceptible to triggers of eryptosis, the same erythrocyte specimens have been used for control and experimental conditions.

\section{Results}

The present study was designed to explore, whether estramustine stimulates eryptosis, the suicidal death of erythrocytes. As eryptosis is triggered by increase of cytosolic $\mathrm{Ca}^{2+}$ activity $\left(\left[\mathrm{Ca}^{2+}\right]_{i}\right)$, Fluo3 fluorescence was employed to estimate $\left[\mathrm{Ca}^{2+}\right]_{i}$. To this end, the erythrocytes were incubated in Ringer solution without or with estramustine $(\leq 100 \mu \mathrm{M})$, loaded with Fluo3 AM and Fluo3 fluorescence quantified by FACS analysis. As illustrated in Fig. 1, a 24 hours exposure of human erythrocytes to estramustine was followed by an increase of Fluo 3 fluorescence, an effect reaching statistical significance at $100 \mu \mathrm{M}$ estramustine concentration. Thus, estramustine treatment was followed by increase of $\left[\mathrm{Ca}^{2+}\right]_{i}$ in human erythrocytes.

An increase of $\left[\mathrm{Ca}^{2+}\right]_{\mathrm{i}}$ is expected to activate $\mathrm{Ca}^{2+}$ sensitive $\mathrm{K}^{+}$channels leading to cellular loss of $\mathrm{KCl}$ together with osmotically obliged water and thus to cell shrinkage. Accordingly, cell volume was estimated from forward scatter in FACS analysis. As shown in Fig. 2, a 24 hours treatment with estramustine did not result in a decrease of forward scatter.

An increase of $\left[\mathrm{Ca}^{2+}\right]_{\mathrm{i}}$ is further expected to trigger cell membrane scrambling with breakdown of phosphatidylserine asymmetry of the cell membrane and appearance of phosphatidsylserine at the cell surface. Accordingly, phosphatidylserine abundance at the cell surface was estimated utilizing annexin V binding in FACS analysis. As shown in Fig. 3, a $24 \mathrm{~h}$ estramustine treatment increased the percentage of annexin $\mathrm{V}$ binding erythrocytes, an effect reaching statistical significance at $50 \mu \mathrm{M}$ estramustine concentration. Accordingly, estramustine triggered cell membrane scrambling.

In order to quantify the effect of estramustine exposure on hemolysis, the percentage of hemolysed erythrocytes was determined from hemoglobin concentration in the supernatant. 
A

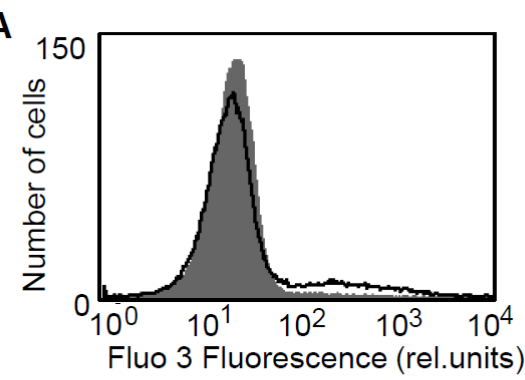

B

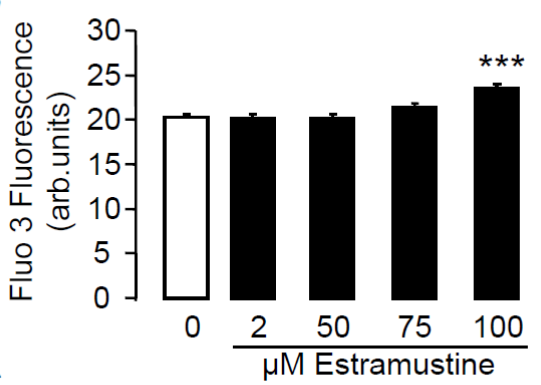

C

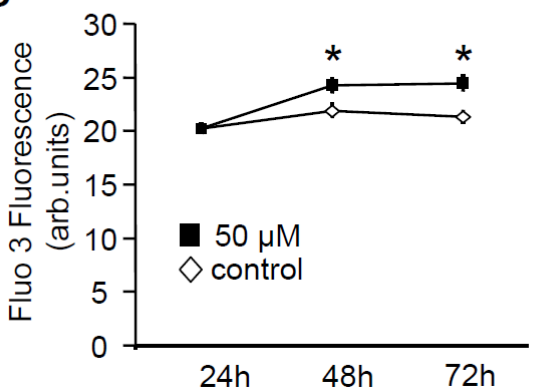

Fig. 1. Effect of estramustine on erythrocyte cytosolic $\mathrm{Ca}^{2+}$ concentration. A. Original histogram of Fluo3 fluorescence in erythrocytes following exposure for $24 \mathrm{~h}$ to Ringer solution without (grey shadow) and with (black line) presence of $100 \mu \mathrm{M}$ estramustine. B. Arithmetic means \pm SEM $(n=15)$ of the Fluo3 fluorescence (arbitrary units) in erythrocytes exposed for $24 \mathrm{~h}$ to Ringer solution without (white bar) or with (black bars) estramustine (2- $100 \mu \mathrm{M})$. ${ }^{* * *}(\mathrm{p}<0.001)$ indicates significant difference from the absence of estramustine (ANOVA). C. Arithmetic means \pm SEM $(n=5)$ of Fluo-3 fluorescence (arbitrary units) in erythrocytes exposed for 24-72 $\mathrm{h}$ to Ringer solution without (white triangles) or with $50 \mu \mathrm{M}$ estramustine (black squares). ${ }^{*}(\mathrm{p}<0.05)$ indicates significant difference from the absence of estramustine.
A

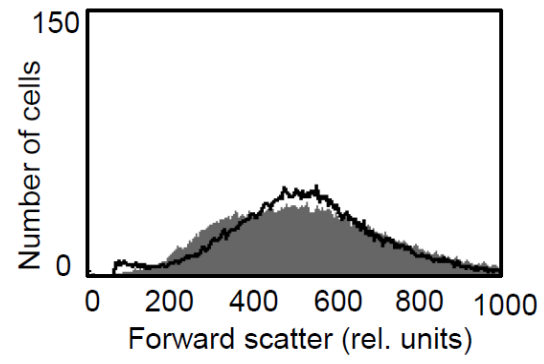

B

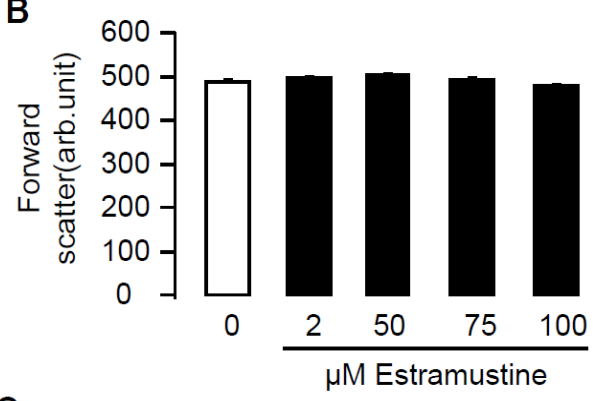

C

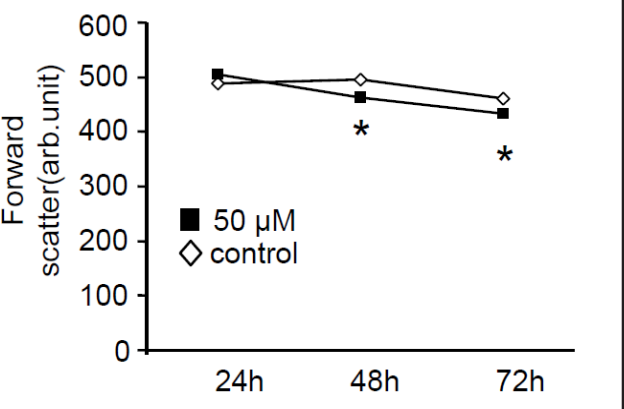

Fig. 2. Effect of estramustine on erythrocyte forward scatter. A. Original histogram of forward scatter of erythrocytes following exposure for $24 \mathrm{~h}$ to Ringer solution without (grey shadow) and with (black line) presence of $100 \mu \mathrm{M}$ estramustine. B. Arithmetic means $\pm \operatorname{SEM}(n=15)$ of the normalized erythrocyte forward scatter (FSC) following incubation for $24 \mathrm{~h}$ to Ringer solution without (white bar) or with (black bars) estramustine (2-100 $\mu \mathrm{M})$. C. Arithmetic means \pm SEM $(n=5)$ of forward scatter (arbitrary units) in erythrocytes exposed for 24-72 h to Ringer solution without (white triangles) or with $50 \mu \mathrm{M}$ estramustine (black squares). ${ }^{*}(p<0.05)$ indicates significant difference from the absence of estramustine.

According to hemoglobin concentration in the supernatant, estramustine treatment resulted in hemolysis, an effect reaching statistical significance at $75 \mu \mathrm{M}$ estramustine concentration (Fig. 4).

Further experiments were performed to test, whether the stimulation of cell membrane scrambling following estramustine treatment was partially or even fully explained by $\mathrm{Ca}^{2+}$ entry from the extracellular space. To this end, erythrocytes were exposed to $100 \mu \mathrm{M}$ 
A

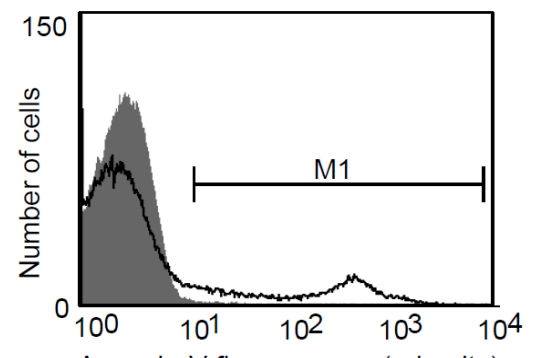

B

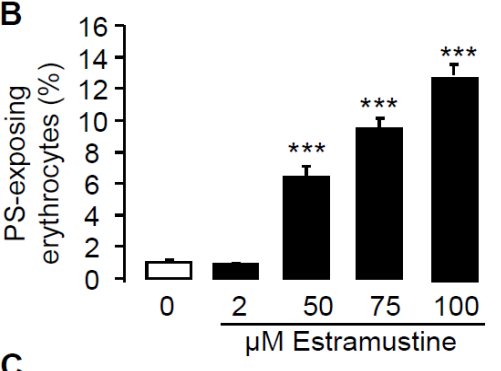

C

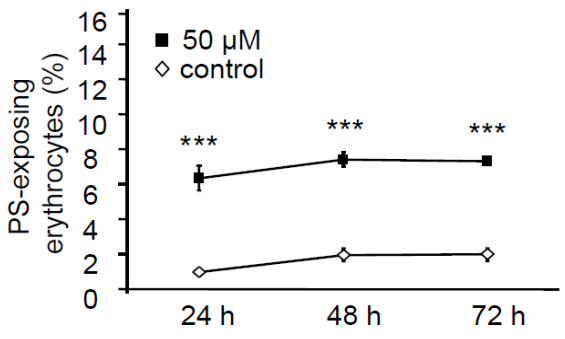

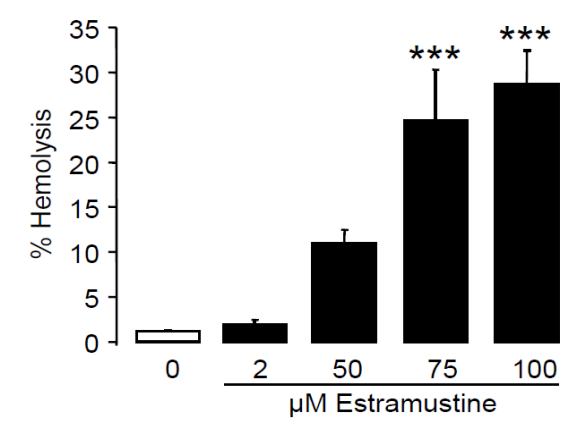

Fig. 4. Effect of estramustine on hemolysis. Arithmetic means \pm SEM $(n=5)$ of hemolysis after a $24 \mathrm{~h}$ incubation in Ringer solution without (white bar) or with (black bars) 2- $100 \mu \mathrm{M}$ estramustine. *** $(\mathrm{p}<0.001)$ indicates significant difference from the control (absence of estramustine) (ANOVA).

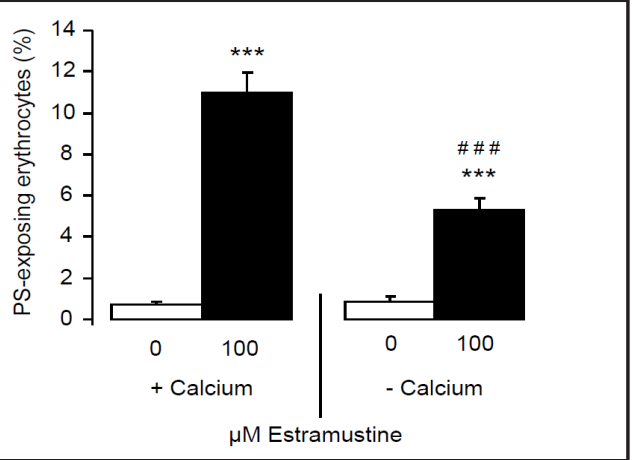

Fig. 5. Effect of $\mathrm{Ca}^{2+}$ withdrawal on estramustine induced annexin $\mathrm{V}$ binding. Arithmetic means \pm SEM $(n=9)$ of the percentage of annexin $V$ binding erythrocytes after a $24 \mathrm{~h}$ treatment with Ringer solution without (white bar) or with (black bars) $100 \mu \mathrm{M}$ estramustine in the presence (left bars, + Calcium) and absence (right bars, - Calcium) of calcium. ${ }^{* * *}(\mathrm{p}<0.001)$ indicates significant difference from the absence of estramustine (ANOVA), \#\#\# $(p<0.001)$ indicates significant difference from the respective values in the presence of $\mathrm{Ca}^{2+}$. trary units) fo solution without (white triangles) or with $50 \mu \mathrm{M}$ estramustine (black squares). ${ }^{* * *}(\mathrm{p}<0.001)$ indicates significant difference from the absence of estramustine.

estramustine for 24 hours in either the presence of $1 \mathrm{mM}$ extracellular $\mathrm{Ca}^{2+}$ or in the absence of extracellular $\mathrm{Ca}^{2+}$ and presence of the $\mathrm{Ca}^{2+}$ chelator EGTA $(1 \mathrm{mM})$. As shown in Fig. 4, removal of extracellular $\mathrm{Ca}^{2+}$ significantly blunted the effect of estramustine on annexin $\mathrm{V}$ binding. However, in the absence of extracellular $\mathrm{Ca}^{2+}$ the percentage annexin $\mathrm{V}$ binding erythrocytes was still slightly, but significantly increased by estramustine treatment (Fig. 5). Thus, estramustine induced cell membrane scambling was in large part but not completely dependent on the presence of extracellular $\mathrm{Ca}^{2+}$.

A final series of experiments explored the effect of estramustine treatment on the formation of ceramide, which would be similarly expected to trigger cell membrane scrambling. Ceramide formation was quantified utilizing FITC-labeled anti-ceramide 
Fig. 6. Effect of estramustine on ceramide formation. A. Original histogram of anti-ceramide FITC fluorescence in erythrocytes after exposure for $24 \mathrm{~h}$ to Ringer solution without (grey shadow) and with (black line) presence of $100 \mu \mathrm{M}$ estramustine. B. Arithmetic means \pm SEM $(n=5)$ of ceramide abundance after a $24 \mathrm{~h}$ incubation in Ringer solution without (white bar) or with (black bars) estramustine $(100 \mu \mathrm{M}) .{ }^{*}(\mathrm{p}<0.05)$ indicates significant difference from the control (absence of estramustine) (ANOVA).

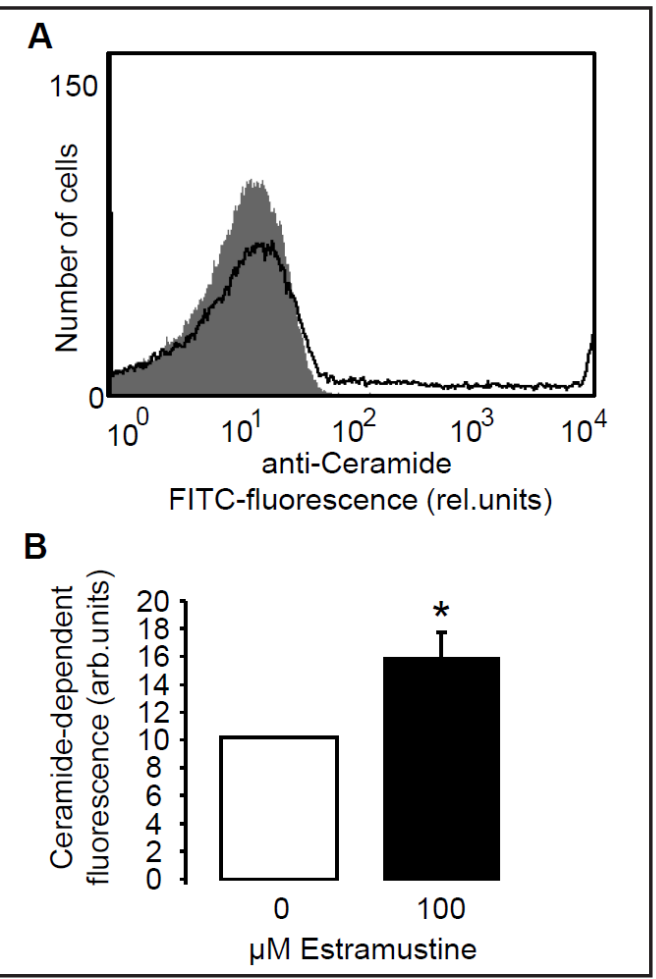

antibodies. As illustrated in Figure 6, the ceramide-dependent fluorescence was significantly higher following a $24 \mathrm{~h}$ exposure to Ringer containing $100 \mu \mathrm{M}$ estramustine than following exposure to Ringer solution without estramustine. Utilizing the secondary antibody alone, the fluorescence did not change significantly upon treatment with estramustine $(-3.8 \pm 1.4 \%$, $n=5$ ). Thus, estramustine indeed significantly enhanced ceramide formation.

\section{Discussion}

The present study explored, whether estramustine triggers eryptosis, the suicidal death of erythrocytes. The results reveal that estramustine treatment of erythrocytes drawn from healthy volunteers is followed by breakdown of phosphatidylserine asymmetry of the cell membrane, a hallmark of eryptosis. The concentrations required to trigger eryptosis are in the range of those concentrations encountered in vivo, which may exceed $100 \mu \mathrm{M}$ [80].

The erythrocyte shrinkage following estramustine treatment is most likely the result of increased cytosolic $\mathrm{Ca}^{2+}$ activity, which activates $\mathrm{Ca}^{2+}$ sensitive $\mathrm{K}^{+}$channels $[16,81]$ leading to cell membrane hyperpolarization. The increased electrical driving force drives $\mathrm{Cl}^{-}$exit and thus leads to cellular loss of $\mathrm{KCl}$ with osmotically obliged water [17].

The breakdown of phosphatidylserine asymmetry of the erythrocyte cell membrane was significantly blunted in the absence of extracellular $\mathrm{Ca}^{2+}$ and was thus again at least in part due to increase of cytosolic $\mathrm{Ca}^{2+}$ activity $\left(\left[\mathrm{Ca}^{2+}\right]_{\mathrm{i}}\right)$. An increase of $\left[\mathrm{Ca}^{2+}\right]_{\mathrm{i}}$ is well known to stimulate cell membrane scrambling with phosphatidylserine translocation from the inner leaflet of the cell membrane to the outer leaflet of the cell membrane [12]. Mechanisms underlying $\mathrm{Ca}^{2+}$ entry include $\mathrm{Ca}^{2+}$ permeable non selective cation channels involving the transient receptor potential channel TRPC6 [14]. The $\mathrm{Ca}^{2+}$ permeable erythrocyte cation channels are activated by oxidative stress [82].

Estramustine-induced phosphatidylserine translocation is blunted but not abolished in the nominal absence of extracellular $\mathrm{Ca}^{2+}$, pointing to involvement of additional mechanisms. Those mechanisms include formation of ceramide, which is known to increase $\mathrm{Ca}^{2+}$ sensitivity of cell membrane scrambling. Moreover, at least in theory, estramustine may influence the 
activity of eryptosis regulating kinases such as AMP activated kinase AMPK [15], casein kinase $1 \alpha[28,29]$, cGMP dependent protein kinase [26], Janus activated kinase JAK3 [27], p38 kinase [30] and/or PAK2 kinase [31].

Triggering of eryptosis has been observed following treatment of erythrocytes with further anticancer drugs [64], including carmustine [83], sorafenib [32], sunitinib [33], cisplatin [84], and paclitaxel [85]. Moreover, eryptosis is enhanced in malignancy [77].

Consequences of enhanced eryptosis include anemia. In vivo, eryptotic erythrocytes are mainly trapped in the spleen and thus rapidly removed from from circulating blood [12]. As soon as the loss of erythrocytes by triggering of eryptosis is not matched by a similar enhancement of erythropoiesis, anemia develops [12].

Consequences of enhanced eryptosis further include adhesion of phosphatidylserine exposing erythrocytes to endothelial CXCL16/SR PSO [86]. The adhesion of erythrocytes to the vascular wall could at least in theory compromize microcirculation and thus interfere with blood flow [86-91]. The effect may be compounded by the stimulating effect of phosphatidylserine exposure on blood clotting, which may foster the development of thrombosis [87, 92,93]. Along those lines, the treatement with estramustine may be associated with an increased risk of thromboembolic events [2].

In conclusion, estramustine triggers $\mathrm{Ca}^{2+}$ entry with subsequent suicidal erythrocyte death or eryptosis. The stimulation of eryptosis may contribute to the development of anemia following estramustine treatment.

\section{Acknowledgements}

The authors acknowledge the meticulous preparation of the manuscript by Ali Soleimanpour. This study was supported by the Deutsche Forschungsgemeinschaft and Open Access Publishing Fund of Tuebingen University.

\section{References}

1 Mohan R, Panda D: Kinetic stabilization of microtubule dynamics by estramustine is associated with tubulin acetylation, spindle abnormalities, and mitotic arrest. Cancer Res 2008;68:6181-6189.

2 Ravery V, Fizazi K, Oudard S, Drouet L, Eymard JC, Culine S, Gravis G, Hennequin C, Zerbib M: The use of estramustine phosphate in the modern management of advanced prostate cancer. BJU Int 2011;108:17821786.

3 Stahlberg K, Kairemo K, Erkkila K, Pentikainen V, Sorvari P, Taari K, Dunkel L, Rannikko S: Radiation sensitizing effect of estramustine is not dependent on apoptosis. Anticancer Res 2005;25:2873-2878.

4 Hong X, Li Y, Hussain M, Sarkar FH: Gene expression profiling reveals novel targets of estramustine phosphate in prostate cancer cells. Cancer Lett 2004;209:187-195.

5 Vallbo C, Bergenheim T, Hedman H, Henriksson R: The antimicrotubule drug estramustine but not irradiation induces apoptosis in malignant glioma involving AKT and caspase pathways. J Neurooncol 2002;56:143-148.

6 Kattan JG, Farhat FS, Chahine GY, Nasr FL, Moukadem WT, Younes FC, Yazbeck NJ, Ghosn MG: Weekly docetaxel, zoledronic acid and estramustine in hormone-refractory prostate cancer (HRPC). Invest New Drugs 2008;26:75-79.

7 Kikuno N, Urakami S, Nakamura S, Hiraoka T, Hyuga T, Arichi N, Wake K, Sumura M, Yoneda T, Kishi H, Shigeno K, Shiina H, Igawa M: Phase-II study of docetaxel, estramustine phosphate, and carboplatin in patients with hormone-refractory prostate cancer. Eur Urol 2007;51:1252-1258.

8 Miyake H, Sakai I, Harada K, Muramaki M, Fujisawa M: Significance of docetaxel-based chemotherapy as treatment for metastatic castration-resistant prostate cancer in Japanese men over 75 years old. Int Urol Nephrol 2012;44:1697-1703. 


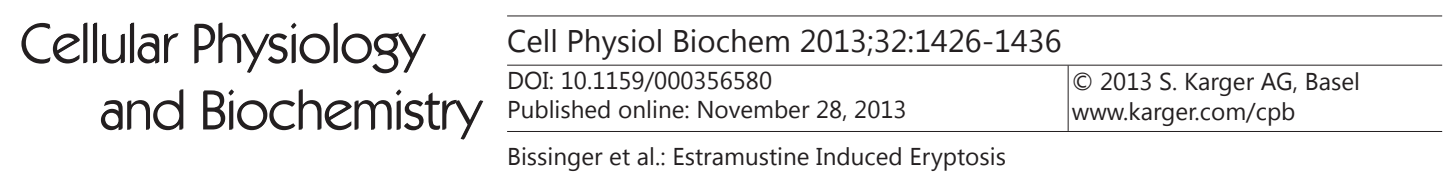

-9 Numata K, Miura N, Azuma K, Karashima T, Kasahara K, Nakatsuzi H, Hashine K, Sumiyoshi Y: Oral estramustine phosphate and oral etoposide for the treatment of hormone-refractory prostate cancer. Hinyokika Kiyo 2007;53:99-104.

10 Yun BH, Hwang EC, Yoo DH, Hwang IS, Kim SO, Jung SI, Kang TW, Kwon DD, Park K, Ryu SB: Comparison of ketoconazole and estramustine for treating patients with castration-resistant prostate cancer. Korean J Urol 2011;52:746-751.

11 Kuramoto T, Inagaki T, Fujii R, Sasaki Y, Nishizawa S, Nanpo Y, Matusmura N, Kohjimoto Y, Hara I: Docetaxel in combination with estramustine and prednisolone for castration-resistant prostate cancer. Int J Clin Oncol 2013;18:890-897.

12 Lang F, Gulbins E, Lerche H, Huber SM, Kempe DS, Föller M: Eryptosis, a window to systemic disease. Cell Physiol Biochem 2008;22:373-380.

13 Foller M, Mahmud H, Qadri SM, Gu S, Braun M, Bobbala D, Hocher B, Lang F: Endothelin B receptor stimulation inhibits suicidal erythrocyte death. FASEB J 2010;24:3351-3359.

14 Foller M, Kasinathan RS, Koka S, Lang C, Shumilina E, Birnbaumer L, Lang F, Huber SM: TRPC6 contributes to the $\mathrm{Ca}^{2+}$ leak of human erythrocytes. Cell Physiol Biochem 2008;21:183-192.

-15 Foller M, Sopjani M, Koka S, Gu S, Mahmud H, Wang K, Floride E, Schleicher E, Schulz E, Munzel T, Lang F: Regulation of erythrocyte survival by AMP-activated protein kinase. FASEB J 2009;23:1072-1080.

16 Brugnara C, de Franceschi L, Alper SL: Inhibition of $\mathrm{Ca}^{2+}$-dependent $\mathrm{K}^{+}$transport and cell dehydration in sickle erythrocytes by clotrimazole and other imidazole derivatives. J Clin Invest 1993;92:520-526.

17 Lang PA, Kaiser S, Myssina S, Wieder T, Lang F, Huber SM: Role of $\mathrm{Ca}^{2+}$-activated $\mathrm{K}^{+}$channels in human erythrocyte apoptosis. Am J Physiol Cell Physiol 2003;285:C1553-C1560.

18 Berg CP, Engels IH, Rothbart A, Lauber K, Renz A, Schlosser SF, Schulze-Osthoff K, Wesselborg S: Human mature red blood cells express caspase- 3 and caspase-8, but are devoid of mitochondrial regulators of apoptosis. Cell Death Differ 2001;8:1197-1206.

19 Lang F, Gulbins E, Lang PA, Zappulla D, Foller M: Ceramide in suicidal death of erythrocytes. Cell Physiol Biochem 2010;26:21-28.

20 Klarl BA, Lang PA, Kempe DS, Niemoeller OM, Akel A, Sobiesiak M, Eisele K, Podolski M, Huber SM, Wieder T, Lang F: Protein kinase C mediates erythrocyte "programmed cell death" following glucose depletion. Am J Physiol Cell Physiol 2006;290:C244-C253.

-21 Bhavsar SK, Bobbala D, Xuan NT, Foller M, Lang F: Stimulation of suicidal erythrocyte death by alpha-lipoic acid. Cell Physiol Biochem 2010;26:859-868.

22 Foller M, Huber SM, Lang F: Erythrocyte programmed cell death. IUBMB Life 2008;60:661-668.

23 Foller M, Mahmud H, Gu S, Wang K, Floride E, Kucherenko Y, Luik S, Laufer S, Lang F: Participation of leukotriene C(4) in the regulation of suicidal erythrocyte death. J Physiol Pharmacol 2009;60:135-143.

-24 Lau IP, Chen H, Wang J, Ong HC, Leung KC, Ho HP, Kong SK: In vitro effect of CTAB- and PEG-coated gold nanorods on the induction of eryptosis/erythroptosis in human erythrocytes. Nanotoxicology 2012;6:847856.

25 Maellaro E, Leoncini S, Moretti D, Del Bello B, Tanganelli I, De Felice C, Ciccoli L: Erythrocyte caspase-3 activation and oxidative imbalance in erythrocytes and in plasma of type 2 diabetic patients. Acta Diabetol 2013;50:489-495.

26 Foller M, Feil S, Ghoreschi K, Koka S, Gerling A, Thunemann M, Hofmann F, Schuler B, Vogel J, Pichler B, Kasinathan RS, Nicolay JP, Huber SM, Lang F, Feil R: Anemia and splenomegaly in cGKI-deficient mice. Proc Natl Acad Sci USA 2008;105:6771-6776.

27 Bhavsar SK, Gu S, Bobbala D, Lang F: Janus kinase 3 is expressed in erythrocytes, phosphorylated upon energy depletion and involved in the regulation of suicidal erythrocyte death. Cell Physiol Biochem 2011;27:547-556.

-28 Kucherenko Y, Zelenak C, Eberhard M, Qadri SM, Lang F: Effect of casein kinase 1alpha activator pyrvinium pamoate on erythrocyte ion channels. Cell Physiol Biochem 2012;30:407-417.

29 Zelenak C, Eberhard M, Jilani K, Qadri SM, Macek B, Lang F: Protein kinase CK1alpha regulates erythrocyte survival. Cell Physiol Biochem 2012;29:171-180.

-30 Gatidis S, Zelenak C, Fajol A, Lang E, Jilani K, Michael D, Qadri SM, Lang F: p38 MAPK activation and function following osmotic shock of erythrocytes. Cell Physiol Biochem 2011;28:1279-1286. 
-31 Zelenak C, Foller M, Velic A, Krug K, Qadri SM, Viollet B, Lang F, Macek B: Proteome analysis of erythrocytes lacking AMP-activated protein kinase reveals a role of PAK2 kinase in eryptosis. J Proteome Res 2011;10:1690-1697.

-32 Lupescu A, Shaik N, Jilani K, Zelenak C, Lang E, Pasham V, Zbidah M, Plate A, Bitzer M, Foller M, Qadri SM, Lang F: Enhanced Erythrocyte Membrane Exposure of Phosphatidylserine Following Sorafenib Treatment: An in vivo and in vitro Study. Cell Physiol Biochem 2012;30:876-888.

-33 Shaik N, Lupescu A, Lang F: Sunitinib-sensitive suicidal erythrocyte death. Cell Physiol Biochem 2012;30:512-522.

-34 Abed M, Towhid ST, Mia S, Pakladok T, Alesutan I, Borst O, Gawaz M, Gulbins E, Lang F: Sphingomyelinaseinduced adhesion of eryptotic erythrocytes to endothelial cells. Am J Physiol Cell Physiol 2012;303:C991999.

-35 Abed M, Towhid ST, Shaik N, Lang F: Stimulation of suicidal death of erythrocytes by rifampicin. Toxicology 2012;302: 23-128.

-36 Bottger E, Multhoff G, Kun JF, Esen M: Plasmodium falciparum-infected erythrocytes induce granzyme B by NK cells through expression of host-Hsp70. PLoS One 2012;7:e33774.

-37 Felder KM, Hoelzle K, Ritzmann M, Kilchling T, Schiele D, Heinritzi K, Groebel K, Hoelzle LE: Hemotrophic mycoplasmas induce programmed cell death in red blood cells. Cell Physiol Biochem 2011;27:557-564.

-38 Firat U, Kaya S, Cim A, Buyukbayram H, Gokalp O, Dal MS, Tamer MN: Increased caspase-3 immunoreactivity of erythrocytes in STZ diabetic rats. Exp Diabetes Res 2012;2012:316384.

-39 Ganesan S, Chaurasiya ND, Sahu R, Walker LA, Tekwani BL: Understanding the mechanisms for metabolism-linked hemolytic toxicity of primaquine against glucose 6-phosphate dehydrogenase deficient human erythrocytes: evaluation of eryptotic pathway. Toxicology 2012;294:54-60.

40 Gao M, Cheung KL, Lau IP, Yu WS, Fung KP, Yu B, Loo JF, Kong SK: Polyphyllin D induces apoptosis in human erythrocytes through $\mathrm{Ca}^{2+}$ rise and membrane permeabilization. Arch Toxicol 2012;86:741-752.

41 Ghashghaeinia M, Cluitmans JC, Akel A, Dreischer P, Toulany M, Koberle M, Skabytska Y, Saki M, Biedermann T, Duszenko M, Lang F, Wieder T, Bosman GJ: The impact of erythrocyte age on eryptosis. Br J Haematol 2012;157:606-614.

-42 Ghashghaeinia M, Toulany M, Saki M, Bobbala D, Fehrenbacher B, Rupec R, Rodemann HP, Ghoreschi K, Rocken M, Schaller M, Lang F, Wieder T: The NFкB pathway inhibitors Bay 11-7082 and parthenolide induce programmed cell death in anucleated Erythrocytes. Cell Physiol Biochem 2011;27:45-54.

43 Jilani K, Lupescu A, Zbidah M, Abed M, Shaik N, Lang F: Enhanced Apoptotic Death of Erythrocytes Induced by the Mycotoxin Ochratoxin A. Kidney Blood Press Res 2012;36:107-118.

44 Jilani K, Lupescu A, Zbidah M, Shaik N, Lang F: Withaferin A-stimulated $\mathrm{Ca}^{2+}$ entry, ceramide formation and suicidal death of erythrocytes. Toxicol In Vitro 2013;27:52-58.

$\$ 45$ Kucherenko YV, Lang F: Inhibitory Effect of Furosemide on Non-Selective Voltage-Independent Cation Channels in Human Erythrocytes. Cell Physiol Biochem 2012;30:863-875.

46 Lang E, Jilani K, Zelenak C, Pasham V, Bobbala D, Qadri SM, Lang F: Stimulation of suicidal erythrocyte death by benzethonium. Cell Physiol Biochem 2011;28:347-354.

47 Lang E, Qadri SM, Jilani K, Zelenak C, Lupescu A, Schleicher E, Lang F: Carbon monoxide-sensitive apoptotic death of erythrocytes. Basic Clin Pharmacol Toxicol 2012;111:348-355.

48 Lang F, Qadri SM: Mechanisms and significance of eryptosis, the suicidal death of erythrocytes. Blood Purif 2012;33:125-130.

-49 Lupescu A, Jilani K, Zbidah M, Lang E, Lang F: Enhanced Ca ${ }^{2+}$ Entry, Ceramide Formation, and Apoptotic Death of Erythrocytes Triggered by Plumbagin. J Nat Prod 2012;10.1021/np300611r

50 Lupescu A, Jilani K, Zbidah M, Lang F: Induction of apoptotic erythrocyte death by rotenone. Toxicology 2012;300:132-137.

51 Lupescu A, Jilani K, Zelenak C, Zbidah M, Qadri SM, Lang F: Hexavalent chromium-induced erythrocyte membrane phospholipid asymmetry. Biometals 2012;25:309-318.

52 Polak-Jonkisz D, Purzyc L: Ca Influx versus Efflux during Eryptosis in Uremic Erythrocytes. Blood Purif 2012;34:209-210.

53 Qadri SM, Bauer J, Zelenak C, Mahmud H, Kucherenko Y, Lee SH, Ferlinz K, Lang F: Sphingosine but not sphingosine-1-phosphate stimulates suicidal erythrocyte death. Cell Physiol Biochem 2011;28:339-346.

54 Qadri SM, Kucherenko Y, Lang F: Beauvericin induced erythrocyte cell membrane scrambling. Toxicology 2011;283:24-31. 
55 Qadri SM, Kucherenko Y, Zelenak C, Jilani K, Lang E, Lang F: Dicoumarol activates $\mathrm{Ca}^{2+}$-permeable cation channels triggering erythrocyte cell membrane scrambling. Cell Physiol Biochem 2011;28:857-864.

56 Qian EW, Ge DT, Kong SK: Salidroside protects human erythrocytes against hydrogen peroxide-induced apoptosis. J Nat Prod 2012;75:531-537.

-57 Shaik N, Zbidah M, Lang F: Inhibition of $\mathrm{Ca}^{2+}$ entry and suicidal erythrocyte death by naringin. Cell Physiol Biochem 2012;30:678-686.

-58 Vota DM, Maltaneri RE, Wenker SD, Nesse AB, Vittori DC: Differential Erythropoietin Action upon Cells Induced to Eryptosis by Different Agents. Cell Biochem Biophys 2016;65:145-157

-59 Weiss E, Cytlak UM, Rees DC, Osei A, Gibson JS: Deoxygenation-induced and $\mathrm{Ca}^{2+}$ dependent phosphatidylserine externalisation in red blood cells from normal individuals and sickle cell patients. Cell Calcium 2012;51:51-56.

60 Zappulla D: Environmental stress, erythrocyte dysfunctions, inflammation, and the metabolic syndrome: adaptations to $\mathrm{CO}_{2}$ increases? J Cardiometab Syndr 2008;3:30-34.

61 Zbidah M, Lupescu A, Jilani K, Lang F: Stimulation of Suicidal Erythrocyte Death by Fumagillin. Basic Clin Pharmacol Toxicol 2013;112:345-351.

62 Zbidah M, Lupescu A, Shaik N, Lang F: Gossypol-induced suicidal erythrocyte death. Toxicology 2012;302:101-105.

63 Zelenak C, Pasham V, Jilani K, Tripodi PM, Rosaclerio L, Pathare G, Lupescu A, Faggio C, Qadri SM, Lang F: Tanshinone IIA stimulates erythrocyte phosphatidylserine exposure. Cell Physiol Biochem 2012;30:282294.

64 Lang E, Qadri SM, Lang F: Killing me softly - suicidal erythrocyte death. Int J Biochem Cell Biol 2012;44:1236-1243.

-65 Calderon-Salinas JV, Munoz-Reyes EG, Guerrero-Romero JF, Rodriguez-Moran M, Bracho-Riquelme RL, Carrera-Gracia MA, Quintanar-Escorza MA: Eryptosis and oxidative damage in type 2 diabetic mellitus patients with chronic kidney disease. Mol Cell Biochem 2011;357:171-179.

66 Nicolay JP, Schneider J, Niemoeller OM, Artunc F, Portero-Otin M, Haik G Jr, Thornalley PJ, Schleicher E, Wieder T, Lang F: Stimulation of suicidal erythrocyte death by methylglyoxal. Cell Physiol Biochem 2006;18:223-232.

67 Myssina S, Huber SM, Birka C, Lang PA, Lang KS, Friedrich B, Risler T, Wieder T, Lang F: Inhibition of erythrocyte cation channels by erythropoietin. J Am Soc Nephrol 2003;14:2750-2757.

68 Lang PA, Beringer O, Nicolay JP, Amon O, Kempe DS, Hermle T, Attanasio P, Akel A, Schafer R, Friedrich B, Risler T, Baur M, Olbricht CJ, Zimmerhackl LB, Zipfel PF, Wieder T, Lang F: Suicidal death of erythrocytes in recurrent hemolytic uremic syndrome. J Mol Med 2006;84:378-388.

69 Kempe DS, Akel A, Lang PA, Hermle T, Biswas R, Muresanu J, Friedrich B, Dreischer P, Wolz C, Schumacher U, Peschel A, Gotz F, Doring G, Wieder T, Gulbins E, Lang F: Suicidal erythrocyte death in sepsis. J Mol Med 2007;85:269-277.

70 Bobbala D, Alesutan I, Foller M, Huber SM, Lang F: Effect of anandamide in Plasmodium Berghei-infected mice. Cell Physiol Biochem 2010;26:355-362.

-71 Foller M, Bobbala D, Koka S, Huber SM, Gulbins E, Lang F: Suicide for survival--death of infected erythrocytes as a host mechanism to survive malaria. Cell Physiol Biochem 2009;24:133-140.

72 Koka S, Bobbala D, Lang C, Boini KM, Huber SM, Lang F: Influence of paclitaxel on parasitemia and survival of Plasmodium berghei infected mice. Cell Physiol Biochem 2009;23:191-198.

73 Lang PA, Schenck M, Nicolay JP, Becker JU, Kempe DS, Lupescu A, Koka S, Eisele K, Klarl BA, Rubben H, Schmid KW, Mann K, Hildenbrand S, Hefter H, Huber SM, Wieder T, Erhardt A, Haussinger D, Gulbins E, Lang F: Liver cell death and anemia in Wilson disease involve acid sphingomyelinase and ceramide. Nat Med 2007;13:164-170.

74 Siraskar B, Ballal A, Bobbala D, Foller M, Lang F: Effect of amphotericin B on parasitemia and survival of plasmodium berghei-infected mice. Cell Physiol Biochem 2010;26:347-354.

75 Lang PA, Kasinathan RS, Brand VB, Duranton C, Lang C, Koka S, Shumilina E, Kempe DS, Tanneur V, Akel A, Lang KS, Foller M, Kun JF, Kremsner PG, Wesselborg S, Laufer S, Clemen CS, Herr C, Noegel AA, Wieder T, Gulbins E, Lang F, Huber SM: Accelerated clearance of Plasmodium-infected erythrocytes in sickle cell trait and annexin-A7 deficiency. Cell Physiol Biochem 2009;24:415-428.

-76 Kempe DS, Lang PA, Duranton C, Akel A, Lang KS, Huber SM, Wieder T, Lang F: Enhanced programmed cell death of iron-deficient erythrocytes. FASEB J 2006;20:368-370. 
77 Qadri SM, Mahmud H, Lang E, Gu S, Bobbala D, Zelenak C, Jilani K, Siegfried A, Foller M, Lang F: Enhanced suicidal erythrocyte death in mice carrying a loss-of-function mutation of the adenomatous polyposis coli gene. J Cell Mol Med 2012;16:1085-1093.

78 Birka C, Lang PA, Kempe DS, Hoefling L, Tanneur V, Duranton C, Nammi S, Henke G, Myssina S, Krikov M, Huber SM, Wieder T, Lang F: Enhanced susceptibility to erythrocyte "apoptosis" following phosphate depletion. Pflugers Arch 2004;448:471-477.

79 Lang KS, Duranton C, Poehlmann H, Myssina S, Bauer C, Lang F, Wieder T, Huber SM: Cation channels trigger apoptotic death of erythrocytes. Cell Death Differ 2003;10:249-256.

-80 Edman K, Svensson L, Eriksson B, Gunnarsson PO: Determination of estramustine phosphate and its metabolites estromustine, estramustine, estrone and estradiol in human plasma by liquid chromatography with fluorescence detection and gas chromatography with nitrogen-phosphorus and mass spectrometric detection. J Chromatogr B Biomed Sci Appl 2000;738:267-279.

81 Bookchin RM, Ortiz OE, Lew VL: Activation of calcium-dependent potassium channels in deoxygenated sickled red cells. Prog Clin Biol Res 1987;240:193-200.

82 Brand VB, Sandu CD, Duranton C, Tanneur V, Lang KS, Huber SM, Lang F: Dependence of Plasmodium falciparum in vitro growth on the cation permeability of the human host erythrocyte. Cell Physiol Biochem 2003;13:347-356.

83 Jilani K, Lang F: Carmustine-induced phosphatidylserine translocation in the erythrocyte membrane. Toxins (Basel) 2013;5:703-716.

-84 Mahmud H, Foller M, Lang F: Suicidal erythrocyte death triggered by cisplatin. Toxicology 2008;249:40-44.

-85 Lang PA, Huober J, Bachmann C, Kempe DS, Sobiesiak M, Akel A, Niemoeller OM, Dreischer P, Eisele K, Klarl BA, Gulbins E, Lang F, Wieder T: Stimulation of erythrocyte phosphatidylserine exposure by paclitaxel. Cell Physiol Biochem 2006;18:151-164.

86 Borst O, Abed M, Alesutan I, Towhid ST, Qadri SM, Foller M, Gawaz M, Lang F: Dynamic adhesion of eryptotic erythrocytes to endothelial cells via CXCL16/SR-PSOX. Am J Physiol Cell Physiol 2012;302:C644-C651.

87 Andrews DA, Low PS: Role of red blood cells in thrombosis. Curr Opin Hematol 1999;6:76-82.

88 Closse C, Dachary-Prigent J, Boisseau MR: Phosphatidylserine-related adhesion of human erythrocytes to vascular endothelium. Br J Haematol 1999;107:300-302.

89 Gallagher PG, Chang SH, Rettig MP, Neely JE, Hillery CA, Smith BD, Low PS: Altered erythrocyte endothelial adherence and membrane phospholipid asymmetry in hereditary hydrocytosis. Blood 2003;101:46254627.

90 Pandolfi A, Di Pietro N, Sirolli V, Giardinelli A, Di Silvestre S, Amoroso L, Di Tomo P, Capani F, Consoli A, Bonomini M: Mechanisms of uremic erythrocyte-induced adhesion of human monocytes to cultured endothelial cells. J Cell Physiol 2007;213:699-709.

-91 Wood BL, Gibson DF, Tait JF: Increased erythrocyte phosphatidylserine exposure in sickle cell disease: flowcytometric measurement and clinical associations. Blood 1996;88:1873-1880.

$\$ 92$ Chung SM, Bae ON, Lim KM, Noh JY, Lee MY, Jung YS, Chung JH: Lysophosphatidic acid induces thrombogenic activity through phosphatidylserine exposure and procoagulant microvesicle generation in human erythrocytes. Arterioscler Thromb Vasc Biol 2007;27:414-421.

-93 Zwaal RF, Comfurius P, Bevers EM: Surface exposure of phosphatidylserine in pathological cells. Cell Mol Life Sci 2005;62:971-988. 